Kinestetik : Jurnal Ilmiah Pendidikan Jasmani 5 (4) (2021)

Kinestetik : Jurnal Ilmiah Pendidikan Jasmani

https://ejournal.unib.ac.id/index.php/kinestetik/index

DOI : 10.33369/jk.v5i4.19772

\title{
DESIGN OF SPEED, AGILITY, QUICKNESS EXERCISES TO IMPROVE THE PHYSICAL FITNESS OF STUDENTS AT THE MUHAMMADIYAH UNIVERSITY OF SURAKARTA IN TERMS OF SPEED AND ENDURANCE
}

\section{Nur Subekti ${ }^{1 *}$, Agam Akhmad Syaukani ${ }^{2}$, Anugrah Nur Warthadi ${ }^{3}$, Amar Abdullah Dani Arni Raihan ${ }^{4}$, Raihan Budianto ${ }^{5}$}

${ }^{12345}$ Muhammadiyah University of Surakarta: Sports Education, Teacher Training and Education Faculty, Universitas Muhammadiyah Surakarta, Sukoharjo, Indonesia

\section{Article Info}

Article History :

Received : December 2021

Revised : December 2021

Accepted : December 2021

Available online : December 2021

Keywords:

Speed, Agility, Quickness, Physical Fitness

\section{Abstract}

The purpose of this study was to determine the design of speed, agility, quickness exercises to improve the physical fitness of students at the Muhammadiyah University of Surakarta. The sample of this study was male students at the Sport Education Study Program, Faculty of Teacher Training and Education, Muhammadiyah University of Surakarta, with some 40 people, purposive sampling was used to determine the sample. This research method uses quasi-experimental research. Data analysis techniques use the constellation one group pretest_posttest design. Data analysis techniques use descriptive analysis and inferential analysis, descriptive analysis is used to describe the results of this study while inferential analysis uses paired sample tests at a significant level $\alpha$ $=0.05$ analysis used with the help of SPSS version 20.0. The results of this study can be concluded. Speed, Agility and Quickness (SAQ) training models namely:(1)"A" Mark Walk, (2) 20-Yard Shuttle, (3) MB Wall Chest Passes, (4) Vertical Jump, (5) Skip For Distance, (6) partner-Resisted Stars, (7) MB Over Head Throw, (8) Standing long Jump, (9) Skip For Height, (10) T-Drill, (11) Bullet Belt, (12) Squrium, (13) Hexagon Drill, (14) Quik Feet, (15) X-pattern Multiskill, (16) Hop-Scotch Drill, (17) Zpattern Ceuts, (18)One-Leg Hop, with a new concept designed according to the needs of Speed, Agility and Quickness (SAQ) training. The SAQ exercise design consisted of (1) cardiorespiratory endurance training; (2) muscle strength and endurance for the upper body, abdomen and lower body; (3) flexibility exercises both dynamic and static; (4) cardiorespiratory endurance activity; (5) endurance and muscle strength activities and (6) forms of flexibility activity.

\footnotetext{
Corresponding address : Senden RT.05/Rw.05, Tohudan Kec.

Colomadu Kabupaten Karanganyar

*Corresponding email : ns584@ums.ac.id

ISSN 2685-6514 (Online)

ISSN 2477-331X (Print)
} 


\section{INTRODUCTION}

The era of modernization restricts a person from physical activity because the daily activities carried out are increasingly easy and practical. Moreover, currently, the world is being faced with the outbreak of the covid-19 virus that has claimed many lives regardless of various backgrounds in social status, education, employment, and no longer know and take into account the color of the skin, ethnicity, or ethnicity, race, even religion, all become one color and close ranks to fight the outbreak that hit the world. Coronavirus infection is called COVID19(Corona Virus Disease 2019)and was first discovered in the chinese city of Wuhan in late December 2019(Almazova et al., 2020; Bard, 2020; Habibi, 2020; Mae \& Toquero, 2020; Nurmidin et al., 2020; Priyastuti \& Suhadi, 2020; Rozi et al., 2021). This virus is transmitted very massively and spreads to all countries, including one of them, in just a few months. This led some countries to implement policies to impose lockdowns to prevent the spread of the Coronavirus (Jariono et al., 2021; Jariono \& Subekti, 2020). Indonesia imposed a policy of imposing restrictions on community activities to suppress the spread of the virus. Efforts to avoid coronavirus are to stay away from crowds, social distance, adhere to health protocols, boost immunity, and exercise.

Looking at the problem to prevent the spread of the COVID-19 outbreak, one of which is to increase the body's immunity through sports activities. This cannot be denied the challenges in the modern era in the face of the covid-19 outbreak to do physical activity urgently require attention, including threats to the quality of life related to health. Quality of life is physical fitness where the condition of the body has an important role in daily activities (Fachrezzy, Hermawan, et al.,
2021; Fachrezzy, Maslikah, et al., 2021; Jariono et al., 2020; Mantu Baro, 2016).

Physical activity to improve physical fitness does not have to be done in open places such as the field, but can be done indoors such as in a fitness center or done at home (stay at home). Moreover, as it is now, to do physical activity, you must follow health protocols. However, this is not a reason not to conduct a study that requires physical activity treatment by complying with health protocols. Starting from the problems above, trying to find answers whether by giving a physical activity training model based on the Speed, Agility and Quickness (SAQ) design can have a good impact on increasing components of physical condition such as increasing immunity in the body (Amar et al., 2017; Azmi \& Kusnanik, 2018; Benny et al., 2015; Bompa \& Buzzichelli, 2015; Mohammad Hasan Basri \& Noer Wahid Riqzal Firdaus, 2020; Yap et al., 2000). So it is expected that through this scientific study can be obtained empirical and accurate information about the level of meaning of the Speed, Agility, and Quickness (SAQ) design activity training model to improve the physical fitness of students of the Muhammadiyah University of Surakarta.

The main objective in the design of speed training, agility, quickness to improve the physical fitness of students of the Muhammadiyah University of Surakarta is reviewed from speed, and endurance.

\section{METHODS}

The method used in this study is quasi-experimentation using the design of pretes_posttest one group design. The free variable is Speed, Agility, and Quickness training while the bonded variable is physical fitness. In this research there are several steps taken, namely " (1) establish the group of research subjects; (2) perform 
a pre-physical fitness test $\left(\mathrm{O}_{1}\right)$; (3) Provide Speed, Agility and Quickness training treatment; (4) Perform a post-physical fitness test (O2); (5) look for pre-test and post-test average scores and compare between the two; (6) look for the difference between the two averages through the statistical method (paired samples test (t_test)

\section{Participants}

The sample of this research is the sports education students of Muhammadiyah University of Surakarta with the sex of male 1 st semester totaling 40 people and the place of this research was carried out at Muhammadiyah University of Surakarta from December 2020 to January 2021.

\section{Sampling Procedures}

Sampling techniques use purposive sampling techniques. Because in this study are male students of sports education, University of Muhammadiyah Surakarta.

\section{Materials and Apparatus}

Data collection is done using the following data collection instruments:

1) Literature studies and research results are used to determine the nature (nature)and scope of the guidance/training system to be developed.

2) Literature studies and research results are used to determine the nature(nature)and scope of Latia Speed, Agility and Quickness (SAQ) design to improve the physical fitness of students of Muhammadiyah Surakarta University sports education.

3) The questioner is used to collect data on the type of speed, agility, and quickness (SAQ) training design to improve the physical fitness of students of sports education at the Muhammadiyah University of Surakarta.

In this study for the treatment of physical activity carried out in the way: 1) for pretest and postest is done by conducting tests gradually by complying with health protocol regulations; 2) students as a sample perform SAQ selfpractice, as a control to perform training students are given the task to document each training session conducted, 3) control during the exercise conducted by students, researchers prepare observation sheets, absences, and rubrics of the exercise program through google formula as a reference to keep doing the exercise, and 4) in this study researchers continue to control exercises online using google meet and others support with this research.

\section{Procedures}

The procedure in this study data collection is carried out using various data collection instruments as follows:

1) General guidelines, containing: rationale, objectives, objectives, systematic activities and allocation of time, place and group characteristics, instructor prerequisites, the role of instructors and trainees, and instructor networking guides.

2) General guidance scale (validation), used to assess the degree of validity, acceptance, feasibility, and validity of the Model.

3) Specific guidelines, containing technical instructions for implementing/using the model for Speed, Agility, and Quickness (SAQ) design activities to improve students' physical fitness. Technical instructions for implementing the model are needed to make it easier for students to understand it 
4) Scale (validation) of specific guidelines, intended to assess the efficacy and ease of the Model.

Furthermore, physical fitness data retrieval techniques only take speed and endurance. For the speed of the researchers running using a run of 60 meters, the purpose of this test is to find out the maximum running speed of students. As for the assessment is the score obtained with the fastest time record ranging from 'yes' to the finish, each candidate is given the opportunity 3 times to take the best time. As for endurance using a multi-stage fitness test (MFT) run

\section{Design or Data Analysis}

Data collected from the results of literature studies, research, and field surveys (physical fitness instruments) of lecturers are analyzed descriptively quality alloy. The goal is to produce a design plan/prototype model, including the basis of theory, problem identification, goal identification, materials, intervention devices, administrative structures/implementation mechanisms, trials, and final products.

Rcangbuild a design activity model Speed, Agility and Quickness (SAQ) to improve the physical fitness of students include:

1) Basic theory, using speed, agility, and quickness (SAQ) design theory to improve a student's physical fitness.

2) Identifying problems, students doing less physical activity

3) Identify model objectives, help increase student independence

4) Materials related to the skills of doing sports activities; including the skills of lecturers in understanding and observing: the way of looking at students, using forms of physical fitness tests, observing the type of feelings of students and the attitude/actions of lecturers, listening, and using messages.

5) The intervention device, created in the form of a guidebook of speed, agility, and quickness (SAQ) design training models to improve students' physical fitness

6) Administrative structure, Focus Group Discussion, Observation Guidelines, and test instruments.

Furthermore, the data used by this study is to use uji_t at a significant level $\alpha=0.05$ to find out the difference between the influence of pretest and post_test speed, and endurance. The overall analysis of this data using SPSS application version 22.0

\section{RESULT}

The research carried out refers to the stages of research as formulated in the research method. The results that have been achieved in this study are as follows

\section{Description of SAQ exercise design}

Overall there are three general objectives to be revealed in the preliminary study or needs analysis, namely: (1) Obtain an overview of the needs of the implementation of Speed, Agility and Quickness (SAQ) training design to improve the physical fitness of students; (2) Obtain an overview of Speed, Agility and Quickness (SAQ) training design to improve students' physical fitness; and (3) Know the results of the validity and practicality of Speed, Agility and Quickness (SAQ) training design to improve students' physical fitness.

Some steps or procedures must be passed in conducting research and development. The preliminary research stage on this research and development is carried out so that the problem becomes 
clearer. At this stage, it is carried out with two main steps, namely: (1) literature studies by reviewing various literature, relevant research results, and other supporting materials, especially related to the concept of Speed, Agility, and Quickness (SAQ) training design to improve students' physical fitness; and (2) field studies which are survey research activities. who seek to explore various information as the main material in conducting need assessment, in addition, this field study is also carried out as technical preparation by exploring in advance the characteristics of the research subject and the place to be conducted research and development. . The following will be explained further related to the results of library studies and field studies as the first step of research and development that will be implemented by researchers.

\section{SAQ Training Design}

The design of Speed, Agility, and Quickness (SAQ) to improve students' physical fitness can be outlined as follows: a. A" Mark Walk how to do this movement is: (i) Use perfect posture and arms as a counterweight; (ii) The knee regards leg recovery, and the foot should be high and remain fully while keeping flexed, ankle close to the gluteus and dorsiflexed. When recovering, the knee is at its highest point; and (iii) the foot should emphasize plantar flexion.

b. 20-YardShuttle, implementation techniques i.e.: (i) Begin the athlete's attitude at the starting line point; (ii) Facing forward, sprinting, and touching the the5-yard (4.5-meter) line continued to run to touch the end of the line with the right hand; (iii) Return to the left, sprint 10 yards (9 meters), and touch the end of the line with the left hand; and(4) Return to the right and sprint 5 yards $(4.5$ meters to completion).

c. MB Wall ChestPasses, the execution technique i.e. (i) Using the wall, making a throw to the wall and receiving the ball with the arm, then the arm straightened back when throwing the ball against the wall; and (ii) This can be done for any number of repetitions, times, or distances.

d. vertical jump, the implementation technique is (i) Stand with the legs shoulder-width apart (with knees and hips flexed in a prestretched position and with the arms back and shoulders above the toes/target) and immediately dip or touch the target with maximum strength. This movement is carried out repeatedly according to the exercise program; (ii) Perform vertical jumps sequentially expanding the ankles, knees, and hips followed by reaching the arms straight into the air; and(iii) adjusted movement reps of the training program.

e. Skip distance, the implementation technique is (i) Miss the knee up and forward as much as possible; (ii) Make the arm action equally aggressively; and (iii) Try to pass as high as possible.

f. Partner-ResistedStars, how to do it is: (i) students refuse (reed) during the first 8 to 10 steps by the couple; (ii) The pair located in front with the hands on the shoulders; or from behind, use a pair's hand or towel around the athlete's waist to fight the start and acceleration phase; and (iii) End movement after 8 to 10 steps.

g. MB Overhead Throw, the implementation technique is (i) Use the wall, load the ball above and behind the head with both hands, expand the entire body; (ii) Throw the ball against the wall with both hands and catch the ball with both hands. 
The medicine ball weighs 4.5 pounds or $2.5 \mathrm{~kg}$, and (iii) the attitude remains parallel and feet flat during exercise.

h. Standing LongJump, the implementation technique is (i) Standing with both feet with shoulders-width separated or slightly narrower; (ii) Load the legs by stretching the knees and hips and tilting the arms backward; and(iii) Pushing the body up and out to distance by expanding the legs and using force to help push the body forward to produce optimal distance.

i. Skip ForHeight, the implementation technique that is (i) Increase the extension and strength of hip flexion; increases the ankle muscles of the legs, increases strength, with long footsteps; (ii) Make the arm react more aggressively; (iii) Try to pass as high as possible in each jump

j. T-Drill, its implementation technique i.e. (i) Set four cones as depicted in the diagram above $(5$ yards $=4.5$ meters, 10 yards $=9$ meters). It starts at a cone (A). At the command of the timer, the testee sprints towards the cone (B) and touches the base of the cone with the right hand; (ii) The testee then turns left and runs sideways touching the cone $(\mathrm{C})$, and also touches the base this time with the testee's left hand. Then run sideways to touch the cone (D) and touch the base with the right hand; and (iii) Then the testee returns to the cone (B) touches with the left hand and runs to his back to head to cone (A). A stopwatch is stopped when the testee touches the cone (A).

k. BulletBelt, its implementation technique i.e. (i) A possible belt will help with a partner while trying to accelerate up to sufficient force; and (ii) There are several techniques used to release and accelerate the athlete/student, including the pop method.

1. Squirm, the technique of implementation is: (i) Starts at a twopoint attitude; (ii) Sprint forward 5 yards (4.5 meters); (iii) Rotate 360 degrees and sprint 5 yards (4.5 meters); and (iv) Rotate 360 degrees again and sprint 5 yards (4.5 meters). Right or left for a 10-yard (9-meter) sprint.

m. Hexagon Drill, the execution technique i.e. (i) Each side of the hexagon is about 2 feet (61 centimeters) long, although this can vary; (ii) Start in the middle of the hexagon facing outward in the specified direction; (iii) Always face in the direction it jumps with both feet outside each side of the hexagon; and (iv) This should be done with both feet, jumping clockwise and counter wise.

n. quick feet, the implementation technique that is walking through an agility ladder, one foot down between each pattern of its strands, concentrating on the speed of the feet, walking at high speeds and reacting to commands, and doing movements according to the specified target.

o. X-Pattern Multiskill,the implementation technique that is (i) Started in several two-point attitudes; (ii) Sprint 10 yards (9 meters) for cone 1; (iii) In cone 1, diagonal sprint 14 yards (13 meters) for cone 2; and(iv) Backpedal 10 yards (9 meters) for cone 3; and(v) In cone 3, diagonal sprint 14 yards (13 meters) for cone 4.

p. Hop-ScotchDrill, the implementation technique that is (i) starting with one foot on each side of the ladder; (ii) Jump with both feet into the first box then to the front of the box with the legs spread apart so that each one lands outside the ladder; (iii) Jump 
with both feet to the front of the square on the ladder; (iv) The movement is repeated continuously; and (v) foresight, not on the ground.

q. Z-PatternCuts, the implementation technique i.e. (i) Begins in some twopoint stance; and (ii) Then the subject sprints to cone 1 , and the subject sprints back with the outer leg, and cuts sharply towards cone 2 .

r. One-LegHop, the technique of its implementation that is Hop in each square, used one foot, press a little when ground contact, foresight, not on the ground. This movement can be done without a ladder as a variation. Speed, Agility, and Quickness (SAQ)

Training design to improve physical fitness in POR UMS students who have been piloted on a small scale and have been revised, then the next stage is to conduct trials to large groups (field tryout). The trial to the Large Group group (FieldTry-out)consisted of POR UMS Students and at the same time conducted trials for test instruments used, conducted against large groups as users of the model which was further revised. The results of data from large group trials are evaluated by lecturers as well as actors and trainers are analyzed to further serve as a foundation to revise the Design of Speed, Agility, and Quickness (SAQ) exercises to improve physical fitness in POR UMS students before testing large groups (field try-out).

Based on the results of field trials, it turns out that the Speed, Agility, and Quickness (SAQ) training design product to improve physical fitness in POR UMS students is nothing to revise, all aspects are already up to standard and very suitable for use. Although there are suggestions from field trial participants to add some aspects of Speed, Agility, and Quickness (SAQ) training design to improve physical fitness in POR UMS students, especially those related to skills such as speed, agility, coordination, balance, and others, on this occasion researchers will not add other variations. In addition to time constraints, researchers also consider that the Speed, Agility, and Quickness (SAQ) training design material to improve physical fitness in POR UMS students is worth using.

To strengthen these results, an inferential analysis was conducted using t_test to determine the improvement of students' physical fitness in terms of speed, and endurance through Speed, Agility, and Quickness (SAQ) exercise. The results of the $t$ _test can be seen in the following table:

Table 1. Results of t_test speed, and endurance analysis

\begin{tabular}{lll}
\hline Test item & Pretest & Sig \\
\hline $\begin{array}{l}\text { Pretest_posttest } \\
\text { speed }\end{array}$ & 16.151 & 0.000 \\
\hline $\begin{array}{l}\text { Pretest_posttest } \\
\text { endurance }\end{array}$ & 29.84 & 0.000 \\
\hline
\end{tabular}

Based on the t_test "pretest and posttest" speed and endurance in table 1 above obtained the values $t_{\text {_count }}$ of 16,151 and 29.84 and $t_{-}$table $\{29: 0.05\}$ respectively. 699. Based on these results, it can be concluded that the correlation coefficient (t-test) between pretest and posttest improvement of student physical fitness is reviewed from significant speed and endurance or $\mathrm{H}_{0}$ rejected and accepted $\mathrm{H}_{1}$. Thus it can be concluded that there is a significant influence on the design of Speed, Agility, and Quickness (SAQ) training to improve the physical fitness of students in terms of speed and endurance. This means that the coefficient can be generalized or can apply to the overall population of sports education students of the Muhammadiyah University of Surakarta where a sample of 40 people is taken. 


\section{DISCUSSION}

Based on the results of the data analysis can be stated that the design of speed training, agility, and quickness (SAQ) to improve physical fitness in students is worth using. Research on improving physical fitness through the exercise approach is widely done, but in this study, researchers conducted an exercise approach by utilizing speed training design, agility, and quickness (SAQ) to improve physical fitness in students.

Research conducted by this study was stated that there was a change in the increase shown by percentage scores through 4 stages of tests, namely pre-test, post-test series 1 , post-test series 2 , and post-test series 3. Programmatic will increase speed and agility for junior taekwondo athletes and does not rule out the possibility to be done by other sports athletes who in such sports require dominating speed and agility. Then the results of Mohammad Hasan Basri's research, (2020) resulted in A speed, agility, and quickness (SAQ) training program that can have an impact on increasing agility, and research conducted by Darumoyo \& Introduction, (2021) produces Speed, agility, and quickness (SAQ) exercise affect the increase in running speed. The results of the study (Govenda et al., 2020) recommend conducting control and testing of the morphology of the study subjects as well as the duration when warming up in future studies. In addition, further research is needed, which examines separately the types of 40-yard sprint and A-movement exercises to find out which types of exercises have a greater influence on speed and agility.

Previous researchers' differences with research conducted by researchers are Speed, Agility, And Quickness Training Design (SAQ) to improve physical fitness in students. This research only involved a sample of the research that is a male student in the sports education study program of the University of Muhammadiyah Surakarta, so this research can only be generalized to the group of male students. Women's samples should also be used as samples because in the design of speed training, agility and quickness (SAQ) to improve physical fitness in students worth using covers in the overall aspect of exercise, to generalize to the characteristics of students.

\section{CONCLUSION}

This research can be concluded that the Design of Speed, Agility And Quickness (SAQ) Exercises to improve physical fitness in students worth using consists of (1) cardiorespiratory endurance exercises; (2) muscle strength and endurance for the upper body, abdominal and lower body; (3) the exercise of flexibility both dynamic and static; (4) cardiorespiratory endurance activity; (5) muscle endurance and strength activity and (6) form of malleability activity. . But this study is only limited to identifying the design of speed training, agility and quickness (SAQ) to improve the physical fitness of students following gender characteristics and limited to male students only. For that, it is necessary to conduct further research involving other variables associated with this study.

\section{ACKNOWLEDGEMENT}

Thank you to the Muhammadiyah University of Surakarta for allowing researchers to research speed, agility, and quickness (saq) exercise design to improve physical fitness involving Muhammadiyah University of Surakarta sports education 
students through regular competitive university research schemes for the 2021 fiscal year.

\section{REFERENCES}

Akhmad, I., Nugraha, T., \& Sembiring, P. (2021). Speed , Agility, and Quickness ( SAQ ) training of the circuit system : How does it affect kick speed and agility of junior taekwondo athletes? Jurnal Sport Area, 6(2), 175-182. https://doi.org/https://doi.org/10.25299/s portarea.2021.vol6(2).6433 Copyright

Almazova, N., Krylova, E., Rubtsova, A., \& Odinokaya, M. (2020). education sciences Challenges and Opportunities for Russian Higher Education amid COVID-19: Teachers ' Perspective. 204.

Amar, I. Y., Subarkah, A., \& Wardoyo, H. (2017). Pengaruh Latihan Saq (Speed, Agility, Quickness) Terhadap Peningkatan Kelincahan Atlet Bulutangkis Kelompok Umur Ganda Remaja Puteri PB. Djarum. Jurnal Ilmiah Sport Coaching and Education. https://doi.org/10.21009/jsce.01105

Azmi, K., \& Kusnanik, N. W. (2018). Effect of Exercise Program Speed, Agility, and Quickness (SAQ) in Improving Speed, Agility, and Acceleration. Journal of Physics: Conference Series. https://doi.org/10.1088/17426596/947/1/012043

Bard, T. R. (2020). COVID-19 and a New Normal? In The journal of pastoral care \& counseling: JPCC. https://doi.org/10.1177/15423050209268 31

Benny, H., Atul, C., \& Najeeb, M. a M. (2015). Effect of Plyometric Training and Saq Training Followed By Detraining on Selected Bio-Motor Abilities of InterCollegiate Level Footballers. International Journal of Physical Education, Fitness and Sports.

Bompa, T., \& Buzzichelli, C. (2015). Periodization Training for Sports-3rd Edition. https://books.google.com/books?id=Zb7 GoAEACAAJ\&pgis $=1$

Darumoyo, K., \& Pendahuluan, A. (2021).
Pengaruh Latihan Speed, Agility, And Quickness ( SAQ ) Terhadap Kecepatan Berlari Dalam Bermain. Sains Olahraga : Jurnal Ilmiah Ilmu Keolahragaan, 5(April), 12-20. http://jurnal.unimed.ac.id/2012/index.ph p/so 12

Fachrezzy, F., Hermawan, I., Maslikah, U., Nugroho, H., \& Sudarmanto, E. (2021). Profile Physical Fitness Athlete of Slalom Number Water Ski. International Journal of Educational Research \& Social Sciences, 2(1), 34-40. https://doi.org/10.51601/ijersc.v2i1.29

Fachrezzy, F., Maslikah, U., Safadilla, E., Reginald, R., \& Hendarto, S. (2021). Physical Fitness Of The Poomsae Taekwondo Athletes In Terms Of Agility, Balance And Endurance. Kinestetik: Jurnal Ilmiah Pendidikan Jasmani, 5(1), 111-119. https://doi.org/10.33369/jk.v5i1.14364

Govenda, R. D., Haryanto, A., Herdyanto, Y., \& Surabaya, U. N. (2020). Peningkatan Kecepatan dan Kelincahan dengan Penggunaan Latihan 40 Yard Sprint dan A-Movement. JOSSAE (Journal of Sport Science and Education), 5, 148-158.

Habibi, A. (2020). Normal Baru Pasca Covid19. Journal.Uinjkt.Ac.Id.

Jariono, G., Nugroho, H., \& Hermawan, I. (2021). The Effect of Circuit Learning on Improving The Physical Fitness of Elementary School Students. International Journal of Educational Research \& Social Sciences, 2(2), 59-68. https://doi.org/https://doi.org/10.51601/ij ersc.v2i1.22

Jariono, G., \& Subekti, N. (2020). Sports Motivation Survey And Physical Activity Students Of Sport Education Teacher Training And Education Faculty Fkip Muhammadiyah. Kinestetik: Jurnal Ilmiah Pendidikan Jasmani, 4(2), 86-95. https://doi.org/https://doi.org/10.33369/j k.v4i2.12449

Jariono, G., Subekti, N., Indarto, P., Hendarto, S., Nugroho, H., Fachrezzy, F., Surakarta, U. M., Sebelas, U., Surakarta, M., \& Jakarta, U. N. (2020). Analisis Kondisi Fisik Menggunakan Software Kinovea Pada Atlet Taekwondo Dojang Mahameru Surakarta. Transformasi: 
Jurnal Pengabdian Masyarakat, 16(2), 133-144.

https://doi.org/https://doi.org/10.20414/tr ansformasi.v16i2.2635

Mae, C., \& Toquero, D. (2020). Inclusion of People with Disabilities amid COVID19: Laws, Interventions, Recommendations. $10(2), \quad 158-177$. https://doi.org/10.4471/remie.2020.5877

Mantu Baro. (2016). Physical Fitness and Wellness - Challenge in the 21st Century. International Journal of Physical Education, Fitness and Sports, 5(1), 2932. https://doi.org/10.26524/1616

Mohammad Hasan Basri, N. W. R. F. (2020). Latihan Speed, Agility And Quickness (SAQ) Untuk Meningkatkan Kelincahan Pada Atlet Futsal Puslatcab Tahun 2020. Jurnal Kejaora: Jurnal Kesehatan Jasmani Dan Olah Raga, 5(November), 62-65.

Mohammad Hasan Basri, \& Noer Wahid Riqzal Firdaus. (2020). Latihan Speed, Agility And Quickness (Saq) Untuk Meningkatkan Kelincahan Pada Atlet Futsal Puslatcab Tahun 2020. Jurnal Kejaora (Kesehatan Jasmani Dan Olah Raga).

https://doi.org/10.36526/kejaora.v5i2.10 33

Nurmidin, M., Fatimawali, \& Posangi, J. (2020). Pengaruh Pandemi Covid-19 Terhadap Aktivitas Fisik dan Penerapan Prinsip Gizi Seimbang pada Mahasiswa Pascasarjana. Journal of Public Health and Community Medicine.

Priyastuti, M. T., \& Suhadi, S. (2020). Kepuasaan Mahasiswa terhadap Pembelajaran Daring Selama Pandemi Covid-19. Journal of Language and Health, 1(2), 49-56. https://doi.org/10.37287/jlh.v1i2.383

Rozi, F., Rahma Safitri, S., Latifah, I., \& Wulandari, D. (2021). Tiga Aspek dalam Pembelajaran Pendidikan Jasmani pada Masa Pandemi Covid-19. Jurnal Kependidikan: Jurnal Hasil Penelitian Dan Kajian Kepustakaan Di Bidang Pendidikan, Pengajaran Dan Pembelajaran, $\quad 239$. https://doi.org/10.33394/jk.v7i1.3220

Yap, C. W., Brown, L. E., \& Woodman, G. (2000). Development of Speed, Agility, and Quickness for the Female Soccer
Athlete. Strength and Conditioning Journal.https://doi.org/10.1519/0012654 8-200002000-00002 